ISSN 1678-4596

\title{
Interference periods of velvet bean in sugarcane
}

\author{
Períodos de interferência de mucuna-preta na cultura da cana-de-açúcar
}

\author{
Fernanda Nunes Bressanin ${ }^{\mathrm{I}}$ Nelson Jayme Neto \\ Mariluce Pascoalina Nepomuceno ${ }^{\mathrm{I}}$ Pedro Luís da Costa Aguiar Alves ${ }^{\mathrm{I}^{*}}$ Willians César Carrega $^{\mathrm{I}}$
}

\section{ABSTRACT}

The objective of the present study was to determine the periods of interference of velvet bean on ratoons of sugarcane cultivar 'RB855536' and to identify its potential for decreasing the crop yield and the quality of the harvested product. The experiment was arranged in a randomized block design, with 18 treatments divided into two groups and four replicates per treatment. In the first group, the sugarcane was kept free from velvet bean interference for nine different periods, beginning at bud sprouting: $0-15,0-30,0-45,0-60,0-90,0-120,0-150$, and 0-180 days after budding (DAB) and 0-harvest. In the second group, sugarcane was grown in coexistence with velvet bean during the same periods described for the first group. The critical period of interference prevention for velvet bean in ratoons of sugarcane $c v$. 'RB 855536' lasted 138 days, from 50 DAB (preinterference period [PIP]) to188 DAB (total period of weed interference prevention [TPIP]). Velvet bean interference caused a $50 \%$ decrease in sugarcane yield and negatively affected the quality of the harvested product.

Key words: Saccharum spp., Mucuna aterrima, weed, competition.

\section{RESUMO}

Objetivou-se determinar os periodos de interferência da mucuna-preta na soqueira cana-de-açúcar, cultivar 'RB855536', e o potencial de redução na produtividade da cultura e na qualidade do produto colhido. Foi utilizado $o$ delineamento experimental em blocos casualizados, com quatro repetições por tratamento, aplicando-se 18 tratamentos divididos em dois grupos. No primeiro, a cultura permaneceu livre da interferência da mucuna-preta desde a brotação até nove épocas do seu ciclo de vida: 0-15, 0-30, 0-45, 0-60, 0-90, 0-120,0-150, 0-180 dias após a brotação (DAB), 0-colheita. No segundo grupo, a cultura permaneceu em convivência com a mucuna-preta desde a brotação até os mesmos periodos descritos anteriormente. $O$ período crítico de prevenção à interferência da mucuna-preta na soqueira da cultura da cana-de-açúcar 'RB 855536' abrangeu 138 dias do ciclo da cultura, de 50 DAB (PAI) a 188 DAB (PTPI). E a redução da produtividade da cana-de-açúcar em decorrência da interferência da mucunapreta foi de $50 \%$, afetando negativamente a qualidade do produto colhido.

Palavras-chave: Saccharum spp., Mucuna aterrima, planta daninha, competição.

\section{INTRODUCTION}

In the past, legumes were widely used in cane field renewal. One of the most commonly used legumes was velvet bean (Mисиna aterrima), mostly due to its green manure properties (AMBROSANO et al., 2013) and high vigor, being able to suppress the establishment of some weed species (SOARES et al., 2012).

However, the inadequate management of the velvet bean resulted in increased amounts of its seeds in the soil, which exhibit dormancy and phased germination, similarly to weeds (CORREIA, 2011; SILVA et al., 2013 and SOUZA et al., 2015). As a result, velvet bean became a weed, currently constituting a serious problem for sugarcane production in the state of São Paulo (GALON et al., 2012; SILVA et al., 2013), with potential for seed dispersal into other areas or

IFaculdade de Ciências Agrárias e Veterinárias (FCAV), Universidade Estadual Paulista (UNESP), Campus de Jaboticabal, 14884-900, Jaboticabal, SP, Brasil. E-mail: plalves@fcav.unesp.br. "Corresponding author. 
states. Similarly to Brachiaria decumbens and Panicum maximum (KUVA et al., 2001, 2003; MARTINELLI et al., 2011),velvet bean can cause decreases in the amount of harvested sugarcane and number of economically viable stalks.

There is currently no information on the effects and periods of interference of velvet bean on sugarcane. Due to its indeterminate vigorous growth and twining and climbing stalks (GARCIA \& MONTEIRO, 1997), velvet bean can cause stalk lodging, damaging crops. Weeds such as morning glory (Ipomoea sp.) can hinder light absorption by sugarcane, and consequently photosynthesis and sucrose formation, when they grow over the top of the sugarcane plant (AZANIA et al., 2011). Velvet bean plants can also quickly over grow other vegetation, smothering and killing all other plants (TEDESCO, 2009), and can make harvest more difficult, compromising the operational performance of harvesters due to machine clogging, limiting the quality of the harvested product.

The time and extension of the period of interference is, without a doubt, the most studied factor determining the degree of interference between weeds and crops (VIDAL et al., 2010). PITELLI and DURIGAN (1984) proposed three periods of weed and crop coexistence: the total period of weed interference prevention (TPIP), pre-interference period (PIP) and critical period of interference prevention (CPIP).

The objective of the present study was to determine the periods of interference of velvet bean on sugarcane and its potential for decreasing crop yield and the quality of harvested sugarcane.

\section{MATERIALS AND METHODS}

Second-cutting ratoons (cultivar 'RB855536') were used, following mechanical harvest performed in October 2012. The local soil is a yellow red dystrophic clay (EMBRAPA, 2006), with clayey texture, $\mathrm{pH} 5.4,13 \mathrm{~g} \mathrm{dm}^{-3}$ organic matter, $19.62 \mathrm{mg} \mathrm{dm}^{-3} \mathrm{P}$ (resin), $2.9 \mathrm{mmol}_{\mathrm{c}} \mathrm{dm}^{-3} \mathrm{~K}, 24 \mathrm{mmol}_{\mathrm{c}}$ $\mathrm{dm}^{-3} \mathrm{Ca}, 8.3 \mathrm{mmol}_{\mathrm{c}} \mathrm{dm}^{-3} \mathrm{Mg}, 50.2 \mathrm{mmol}_{\mathrm{c}} \mathrm{dm}^{-3}$ cation exchange capacity (CEC) and $70.12 \mathrm{~V} \%$. The local climate is Cwa subtropical according to the Köppen climate classification, with short, mild and dry winters and hot and rainy summers, with two well-defined seasons.

The experiment was established in December 2012, when the cane field was beginning to bud (average of 25 tillers $\mathrm{m}^{-1}$ ). The area was cultivated mechanically and fertilized with $178 \mathrm{~kg}$ $\mathrm{ha}^{-1}$ NPK (20-0-20). Experimental area was chosen due to its history of natural infestation by velvet bean. Weeds other than velvet bean were removed through selective weeding. A randomized block experimental design was used, with four replicates per treatment. The experimental plots measured $75 \mathrm{~m}^{2}(10 \mathrm{~m}$ length $\mathrm{x} 5$ rows spaced $1.5 \mathrm{~m}$ apart $)$, with one row on each side of the plot and one meter on the two extremes of the rows as border, resulting in $36 \mathrm{~m}^{2}$ useful area.

A total of 18 treatments were tested, separated into two groups. In the first group, nine different velvet bean interference-free periods were tested, starting at budding: $0-15,0-30,0-45$, $0-60,0-90,0-120,0-150$, and 0-180 days after budding (DAB), as well as 0 -harvest. In the second group, sugarcane was grown in coexistence with velvet bean during the same periods described for the first group.

Velvet bean samples were collected at the end of determined periods, using iron quadrates with sides $0.5 \mathrm{~m}$ in length and $0.25 \mathrm{~m}^{2}$ internal area. The quadrates were randomly thrown eight times inside the useful area of the experimental plots. Plants inside the quadrates were collected, and their dry weight was measured. For the weed-free treatments (first group), velvet bean samples were collected during sugarcane harvest, using iron quadrates with $1 \mathrm{~m}^{2}$ internal area. Plants inside the quadrate were collected, and their dry weight was measured.

Sugarcane stalk yield was estimated through biometric measurements performed 12 months following the previous harvest, without straw burning. Total number of stalks fit for industrial processing was counted. The mean weight of ten stalks from each of the three central rows of the experimental plots, excluding the borders, was calculated and extrapolated to $t$ $\mathrm{ha}^{-1}$. Ten stalks from each treatment were also collected at harvest to evaluate the following qualitative parameters of the juice, according to CONSECANA (2006): fiber content, Brix, purity and total recoverable sugars (TRS). The yield data were subjected to regression analysis using the Boltzmann sigmoidal model, according to KUVA et al. (2001), to determine the periods of interference of velvet bean, considering an arbitrary level of 5\% acceptable yield loss.

Regression analysis was also performed for the relationship between velvet bean accumulated dry weight and sugarcane yield and TRS, measured for the different coexistence and 
weed-free (control) periods tested. Qualitative parameters of the juice were subjected to analysis of variance using the F test followed by Tukey's test, at $5 \%$ probability.

\section{RESULTS AND DISCUSSION}

In all samplings, approximately $98 \%$ of the weed community consisted of velvet bean. The accumulated dry weight of velvet bean increased with increasing coexistence period until $179 \mathrm{DAB}$, reaching $233 \mathrm{~g} \mathrm{DWm}^{-2}$, even though the plants were likely being shaded by sugarcane (Figure 1). Dry weight accumulation was higher starting at $120 \mathrm{DAB}$, for which a rate of dry weight accumulation of $3 \mathrm{~g}$ day $^{-1}$ was observed. Velvet bean has very fast initial growth, covering $99 \%$ of the soil surface 58 days after seedling emergence (FAVERO et al., 2001).

Without control of velvet bean during the whole crop cycle, velvet bean accumulated approximately $231 \mathrm{~g} \mathrm{DW} \mathrm{m}^{-2}$ until harvest. Dry weight accumulation decreased with increasing weed-free period (Figure 1). Control of velvet bean until 44
DAB was sufficient to considerably decrease $(65 \%)$ its dry weight accumulation. At $120 \mathrm{DAB}$, the dry weight remained constant, at approximately $25 \mathrm{~g}$ DW $\mathrm{m}^{-2}$. When used as green manure, the normal yield of velvet bean is 6 to $8 \mathrm{t} \mathrm{DWha}^{-1}$ or 0.6 to $0.8 \mathrm{~kg} \mathrm{DW}$ $\mathrm{m}^{-2}$ (BRAGA et al., 2006). However, FERRAZ and LOPES (2003) reported velvet bean to produce up to $35 \mathrm{t} \mathrm{ha}^{-1}$ green biomass.

Regression analysis showed an exponential decrease in sugarcane yield with increasing velvet bean dry weight, for both types of coexistence (Figure 2). When velvet bean coexisted with sugarcane in the beginning of the crop cycle, accumulation of $4.37 \mathrm{~g} \mathrm{DW} \mathrm{m}^{-2}$ velvet bean resulted in a sugarcane yield decrease of $1 \mathrm{t}$ $\mathrm{ha}^{-1}$. Sugarcane yield was estimated at $98.85 \mathrm{tha}^{-1}$ and decreased approximately $50 \%$, to $53 \mathrm{tha}^{-1}$, with the increase in velvet bean dry weight to approximately $232 \mathrm{~g} \mathrm{~m}^{-2}$. As observed for velvet bean, dry weight increases in other weed species are expected to result in decreased sugarcane yield. KUVA et al. (2003) observed a negative correlation between weed dry weight accumulation and sugarcane stalk production, with $3.26 \mathrm{~g} \mathrm{~m}^{-2}$ signal grass

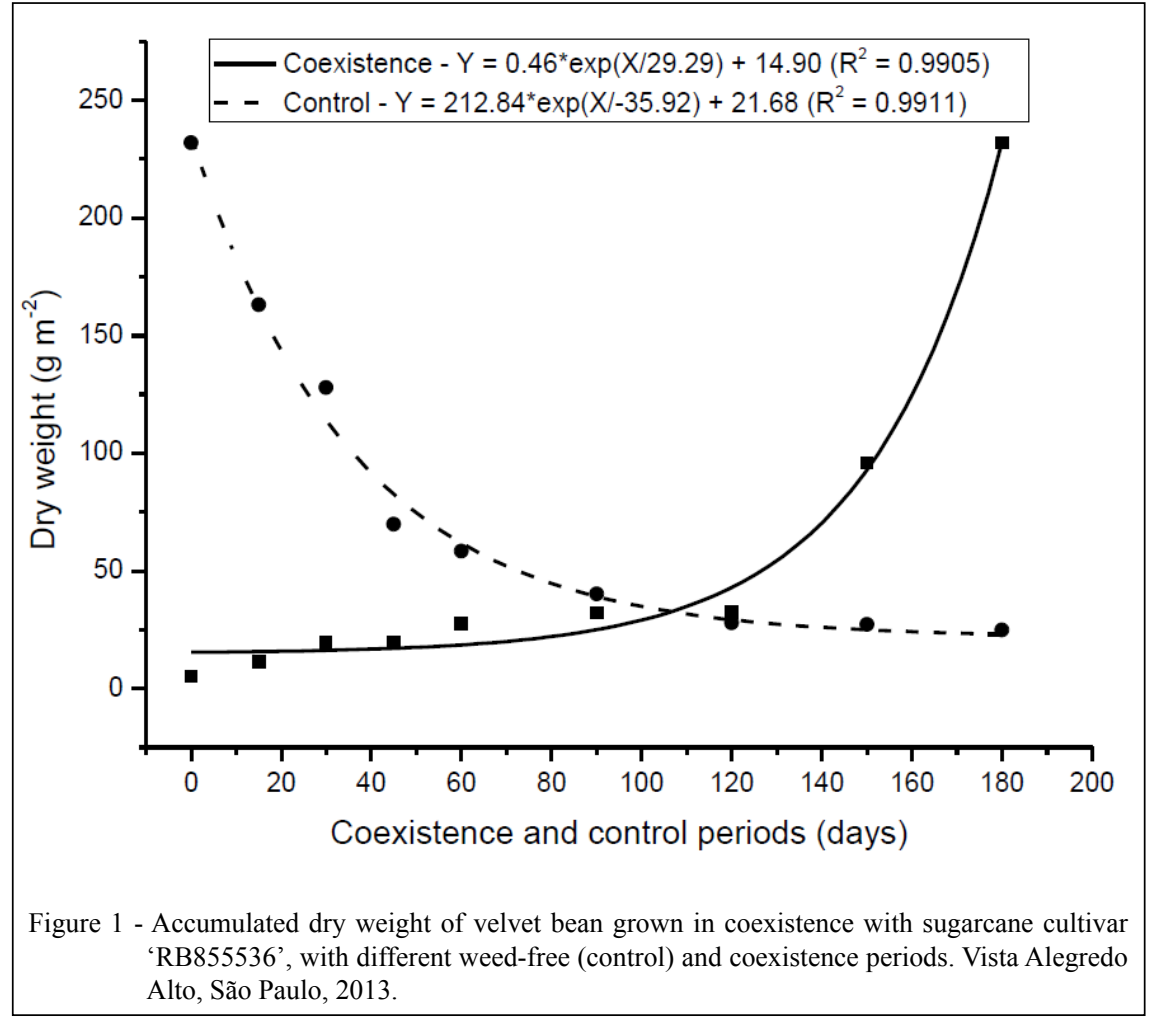

Ciência Rural, v.46, n.8, ago, 2016. 


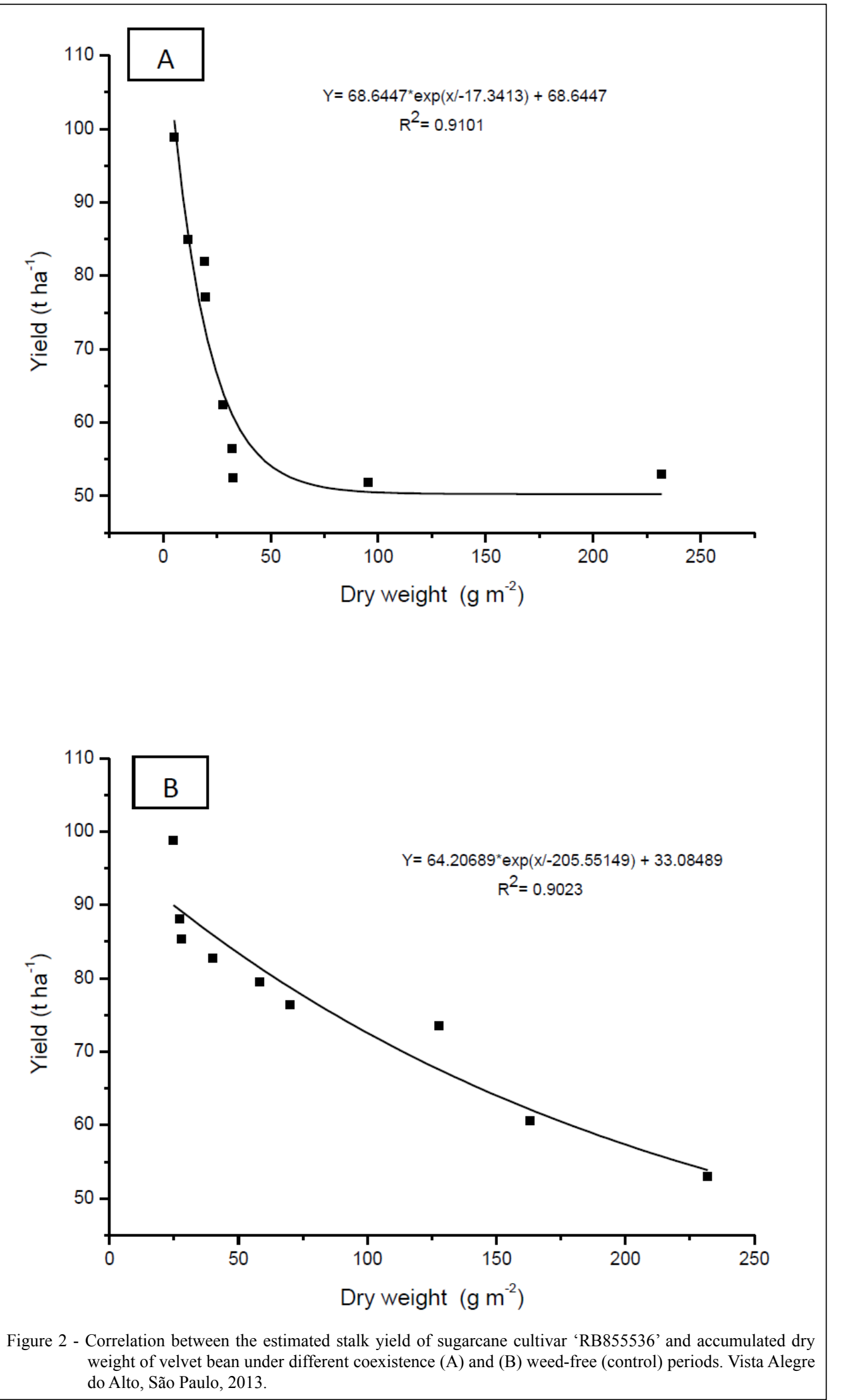

Ciência Rural, v.46, n.8, ago, 2016. 
(Brachiaria decumbens) and $1.27 \mathrm{~g} \mathrm{~m}^{-2}$ guinea grass (Panicum maximum) causing a decrease of $1 \mathrm{t} \mathrm{ha} \mathrm{a}^{-1}$ in sugarcane stalk yield.

Sugarcane yield has been observed to decrease up to $46 \%$ due to interference of $\boldsymbol{I}$. hederifolia (SILVA et al., 2009) and up to $24 \%$ due to interference of plants from the genera Ipomoea, Merremia and Euphorbia (AZANIA et al., 2009). A 33.4\% decrease in ratoon cane yield was observed due to a weed community with predominance of Acanthospermum hispidum, Alternanthera tenella and Panicum maximum (MEIRELLES et al., 2009).

Considering a maximum acceptable level of $5 \%$ yield loss, the sugarcane was negatively affected by coexistence with velvet bean beginning at $50 \mathrm{DAB}$ (corresponding to the PIP) (Figure 3). Control of velvet bean until 188 DAB was necessary for yield losses to remain under $5 \%$ relative to the maximum production level (corresponding to TPIP). Thus, the critical period of interference prevention (CPIP), i.e., of velvet bean control, was between 50 and 188 DAB. Control measures; therefore, need to be adopted starting at $50 \mathrm{DAB}$ that can effectively eliminate velvet bean up to $188 \mathrm{DAB}$.

The CPIP is the period that should be covered by weeding or the effect of herbicides because weeds already present at the area together with those that emerge during this period are in a stage of development that will interfere with, and significantly decrease, crop yield (PITELLI, 1985). Different studies of weed interference on sugarcane have found different total periods of interference prevention (TPIP). A TPIP of 138 days after planting (DAP) was reported for interference of signal grass (KUVA et al., 2001), of 127 DAP for guinea grass and signal grass (KUVA et al., 2003), and of 137 DAB for interference of $\boldsymbol{A}$. hispidum, A. tenella and $\boldsymbol{P}$. maximum on ratoon cane (MEIRELLES et al., 2009).

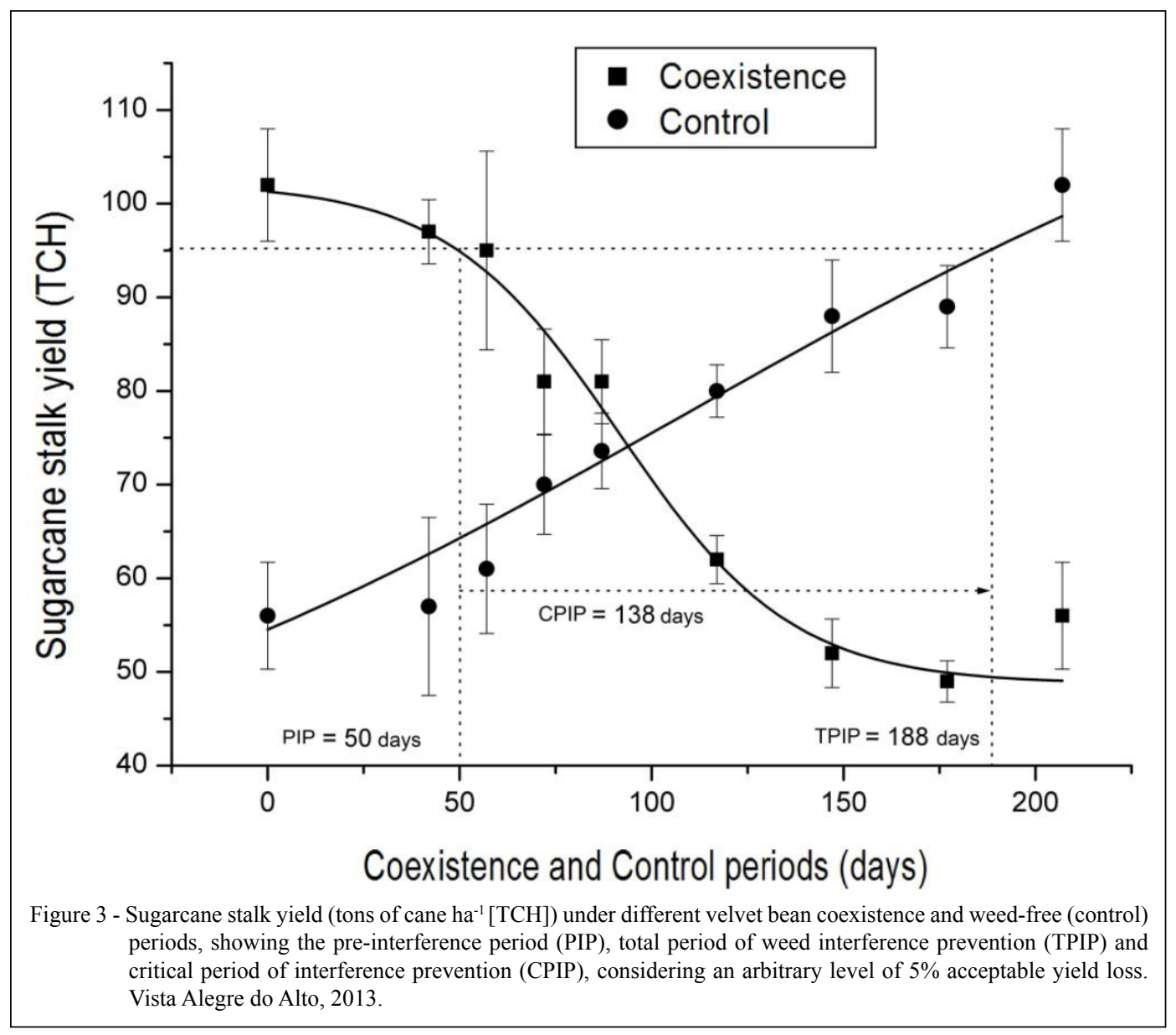

Ciência Rural, v.46, n.8, ago, 2016. 
Significant differences in qualitative parameters of sugarcane juice were observed between treatments. For the weed-free (control) treatments, the lowest Brix, saccharose apparent (Pol) and purity values were observed for the treatments with the shortest weed-free periods, $0-15,0-30$ and 0-45 DAB, being below the recommended values of $18 \%$ Brix, $14 \%$ Pol and equal or higher than $85 \%$ purity (RIPOLI $\&$ RIPOLI, 2004). For the coexistence treatments, the lowest Brix, Pol and purity values were also observed for treatments with longer periods of coexistence with velvet bean. Brix was lower than recommended for the treatments $0-150$ and 0-180 DAB and 0-harvest, purity was lowest for the treatments $0-180 \mathrm{DAB}$ and 0 -harvest, and Pol was lower than recommended only for the coexistence treatment 0 -harvest. The highest mean fiber contents were observed for the weed-free treatment $0-90 \mathrm{DAB}(11.22 \%)$ and for the coexistence treatments $0-15$ (11.24\%) and 0-45 DAB (11.06\%).

The levels of total recoverable sugars (TRS) per unit weight $\left(\mathrm{kg} \mathrm{t}^{-1}\right)$ gradually decreased with increasing coexistence period. The TRS for the weed-free treatment (0-harvest) was adequate because sugarcane was harvested at its optimal harvesting time. Sugarcane should be harvested in July/August (PMGCA, 2008), and the experimental plots were harvested on 2 July 2013. The gradual decrease in TRS may have been because velvet bean is a climbing shrub that tends to wrap itself around sugarcane, breaking sugarcane stalks and causing smothering and consequent rotting of stalks.

SILVA et al. (2009) tested different periods of coexistence of I. hederifolia with the same sugarcane cultivar used in the present study and observed no differences in TRS. This result was likely because the authors harvested the sugarcane seven months after budding instead of during its optimal harvesting time.

The TRS levels were higher for shorter coexistence periods (Figure 4). TRS levels were $29.30 \%$ lower with coexistence until 180 DAB than for the control without velvet bean coexistence. This

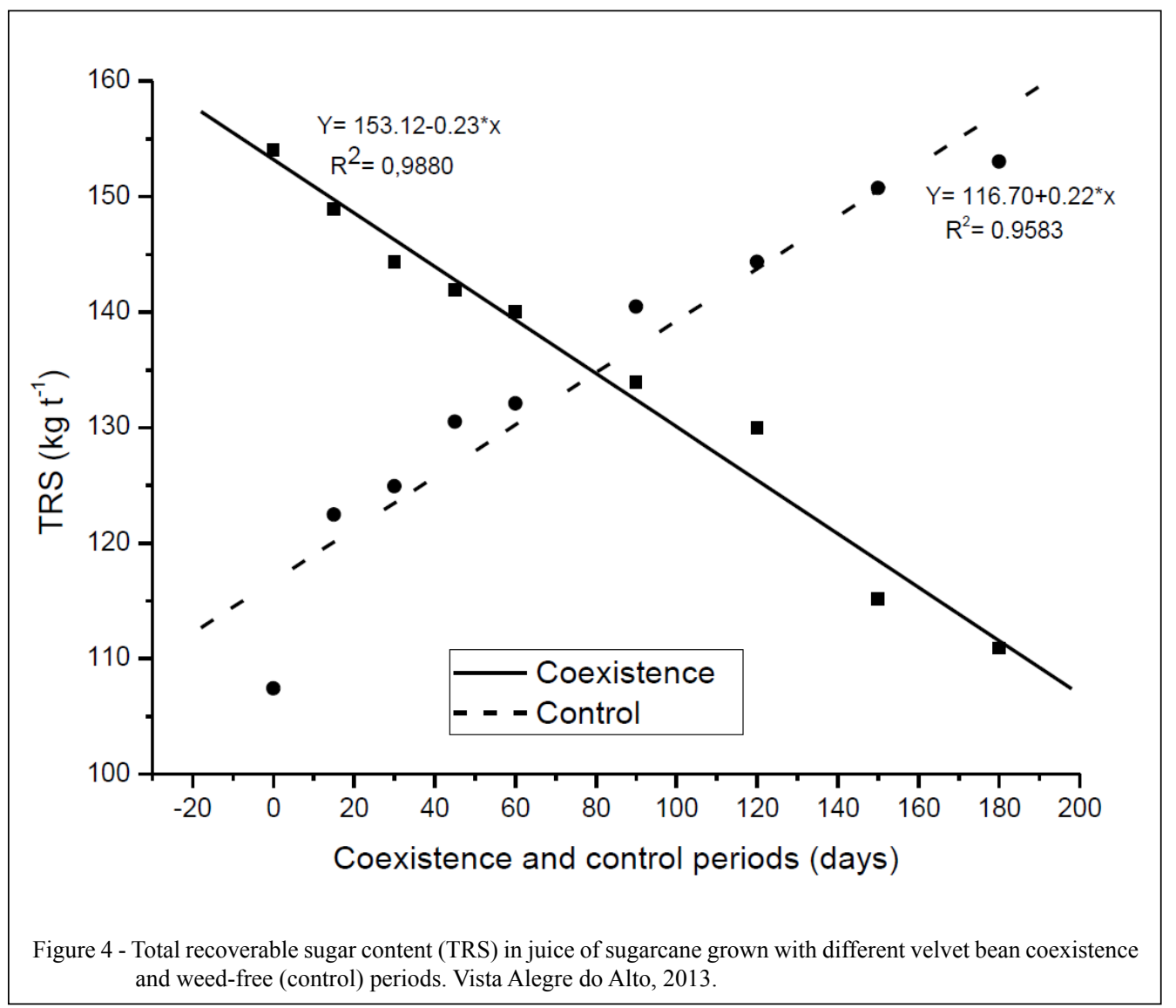

Ciência Rural, v.46, n.8, ago, 2016. 
decrease in TRS is not economically acceptable because sugarcane is currently priced based on the TRS concentration (sucrose, glucose and fructose) of the raw material when it reaches processing (SACHS, 2007).

\section{CONCLUSION}

The critical period of interference prevention for velvet bean on ratoon sugarcane (cultivar ' $R B$ 855536 ') lasted 138 days, from 50 DAB (PIP) to 188 DAB (TPIP). Velvet bean interference caused a $50 \%$ decrease in sugarcane yield and negatively affected the quality of the harvested product, which exhibited decreased quality parameters.

\section{ACKNOWLEDGEMENTS}

Fundação de Amparo à Pesquisa do Estado de São Paulo (FAPESP), Conselho Nacional de Desenvolvimento Científico e Tecnológico $(\mathrm{CNPq})$ provided scholarships to the first (Proc. n.2012/04775-4) and last (Proc. n.311281/2013-3) authors, respectively.

\section{REFERENCES}

AMBROSANO, E.J.et al. Mass and nutrient accumulation by green manures and sugarcane plant yield grown in succession, in two locations of Sao Paulo, Brazil. Revista Brasileira de Agroecologia, v.8, n.1, p.199-209, 2013. Available from: <http:// www.aba-agroecologia.org.br/revistas/index.php/rbagroecologia/ article/view/12944> . Accessed: Jan. 20, 2015. ISSN: 1980-9735.

AZANIA, C.A.M.et al. Chemical Management of Convolvulaceae and Euphorbiaceae in Sugarcane during Dry Season. Planta Daninha, v.27, n.4, p.841-848, 2009. Available from: <http:// dx.doi.org/10.1590/S0100-83582009000400023>. Accessed: Jan. 20, 2015. doi: 10.1590/S0100-83582009000400023.

AZANIA, C.A.M.et al. Biologia e manejo químico de corda-deviola em cana-de-açúcar. Campinas: Instituto Agronômico (IAC), 2011. 18p. (Boletim Técnico IAC, 209). Available from: <http:// www.iac.sp.gov.br/publicacoes/publicacoes.../Boletim 209 FINAL.pdf>. Accessed: Jan. 20, 2015.

BRAGA, N.R. et al. Mucuna-preta. Campinas: IAC, 2006. Available from: <http://wwwiac.sp.gov.br/Tecnologias/ MucunaPreta/MucunaPreta.htm>. Accessed: Aug. 30, 2006.

CONSECANA: Manual de instruções. 5.ed. Piracicaba, SP, 2006. p.48-53. Available from: <http://www.unica.com.br/publicaçoes>. Accessed: Oct. 25, 2015

CORREIA, N.M. Eficácia do mesotrione aplicado isolado e em mistura para o controle de corda-de-viola e de mucuna-preta em cana-soca. Álcoolbras, n.133, p.46-51, 2011

EMBRAPA (EMPRESA BRASILEIRA DE PESQUISA AGROPECUÁRIA). Sistema brasileiro de classificação de solos. 2.ed. Rio de Janeiro: Centro Nacional de Pesquisa de Solos, 2006. 306p
FAVERO, C.et al. Modifications in the population of spontaneous plants in the presence of green manure. Pesquisa Agropecuária Brasieira, v.36, n.11, p.1355-1362, 2001. AvaLible from: <http:/ www.scielo.br/pdf/pab/v36n11/6808.pdf>. Acessed: Dec.13, 2014. doi: 10.1590/S0100-204X2001001100005

FERRAZ, S. LOPES, E.A. Mucunapreta: aplanta mágica. In: CONGRESSO BRASILEIRO DE NEMATOLOGIA, 24., 2003, Petrolina, PE. Programas e resumos... Petrolina: Sociedade Brasileira de Nematologia: Embrapa Semi-Árido, 2003. p.64-67.

GALON, L.et al. Macronutrients availability in sugarcane varieties grown under increasing densities of Brachiaria brizantha. Ciência Rural, v.42 n.8, p.1372-1379, 2012. Available from: <http:// dx.doi.org/10.1590/S0103-84782012000800007>. Accessed: Dec. 12, 2014. doi: 10.1590/S0103-84782012000800007.

GARCIA, F.C.P. et al. Leguminosae-Papilionidae de uma floresta pluvial de planície costeira. Naturalia, v.22, p.17-60, 1997.

KUVA, M.A.et al. Interference periods of weeds in the sugarcane crop. II -Brachiaria decumbens. Planta Daninha, v.19, n.3, p.323-330, 2001. Available from: <http://dx.doi.org/10.1590/ S0100-83582001000300003>. Accessed: Dec. 12, 2014. doi $10.1590 / \mathrm{S} 0100-83582001000300003$

KUVA, M.A.et al. Interference Periods of Weeds in the Sugarcane Crop. III - Brachiaria decumbens and Panicum maximum. Planta Daninha, v.21, n.1, p.37-44, 2003. Available from: <http:// dx.doi.org/10.1590/S0100-83582003000100005>. Accessed: Mar. 12, 2014. doi: 10.1590/S0100-83582003000100005.

MARTINELLI, C.A.et al. Interferência de plantas daninhas na cultura da cana-de-açúcar e algumas práticas de controle. Revista Científica Eletrônica de Agronomia, v.20, p.1-6, 2011. Available from: $<$ http://faef.revista.inf.br/site/e/agronomia-20-edicaodezembro-de-2011.html\#tab649>. Accessed: Dec. 12, 2014.

MEIRELLES, G.etal. Weed interferenceperiods in ratoon sugarcane. Planta Daninha, v.27, n.1, p.67-73, 2009. Available from: <http:// dx.doi.org/10.1590/S0100-83582009000100010>. Accessed: Dec. 12, 2014. doi: 10.1590/S0100-83582009000100010.

PITELLI, R.A.; DURIGAN, J.C.Terminologia para períodos de controle e de convivência das plantas daninhas em culturas anuais e bianuais. Resumos... In: CONGRESSO BRASILEIRO DE HERBICIDAS E PLANTAS DANINHAS, Belo Horizonte: SBHED, 1984. p.37-37.

PMGCA (PROGRAMA DE MELHORAMENTO GENÉTICO DE CANA-DE-AÇÚCAR do CCA/Ufscar). Variedades RB. Primeira Edição - Novembro 2008. Available from: <https:// www.agencia.cnptia.embrapa.br/Repositorio/VariedadesRB 2008+apostila_000fxga3a3302wyiv80soht9hetswek2.pdf $>$. Accessed: Mar. 31,2014

RIPOLI, T.C.C.; RIPOLI, M.L.C. Biomassa de cana-de-açúcar colheita, energia e ambiente. Piracicaba, Edição dos autores, 2004. 302p.

SACHS, R.C.C. Remuneração da tonelada de cana-de-açúcar no Estado de São Paulo. Informações Econômicas, v.37, n.2, p.1115, 2007. Available from: <ftp://ftp.sp.gov.br/ftpiea/publicacoes/ tec5-0207.pdf>. Accessed: Dec. 14, 2014

SILVA, I.A.B.et al. Overcoming depth sowing and mulch density in Mucuna aterrima, Mucuna deeringiana and Mucuna 
cinerea. Planta Daninha, v.31, n.2, p.313-317, 2013. Available from: $\quad<$ http://dx.doi.org/10.1590/S0100-83582013000200008>. Accessed: 25 Oct. 25, 2015.

SILVA, I.A.B. et al. Interference of a weed community with predominance of Ipomoea hederifolia on sugar cane ratton. Planta Daninha, v.27, n.2, p.265-272, 2009. Available from: $<$ http://dx.doi.org/10.1590/S0100-83582009000200008>. Accessed: Dec. 12, 2014. doi: 10.1590/S010083582009000200008 .

SOARES, M.B.B.et al. Plantas daninhas em área de reforma de cana crua com diferentes manejos do solo e adubos verdes em sucessão. Revista Agro@mbiente On-line, v.6, n.1, p.25-33, 2012. Available from: <http://revista.ufrr.br/index.php/agroambiente/ article/view/683>. Accessed: Mar. 12, 2014.
SOUZA, G.C. et al. Germinação de sementes de mucunapreta submetidas a diferentes períodos de armazenamento. Revista Brasileira de Energia Renováveis, v.4, p.72-83, 2015. Available from: <http://ojs.c3sl.ufpr.br/ojs/index.php/rber/article/ view/37692/pdf_44>. Accessed: Oct, 25, 2015.

TEDESCO, V. Utilização de Mucuna-preta como alternativa ao uso do fogo. AscomRO, 2009. Available from: <http://www. ecodebate.com.br>. Accessed: Mar. 15, 2012.

VIDAL, R.A.et al. Interference and economic threshold of Brachiaria plantaginea and Ipomoea nil in the common bean crop. Ciência Rural, v.40, n.8, p.1675-1681, 2010. Available from: <http://dx.doi.org/10.1590/S010384782010000800001>. Accessed: Aug. 29, 2015. doi: 10.1590/ S0103-84782010000800001. 


\section{ERRATUM}

Artigo "Interference periods of velvet bean in sugarcane" publicado no fascículo v46n8 de agosto da Ciência Rural páginas 1329-1336, onde se lia:

“Approved 02.22.15”

leia-se:

“Approved 02.22.16"

Para a versão correta, acesse:

http://www.scielo.br/pdf/cr/v46n8/1678-4596-cr-46-08-01329.pdf 


\section{ERRATA}

No artigo "Interference periods of velvet bean in sugarcane " publicado no fascículo v46n8, páginas 1329-1336, faltou a inclusão do autor Willians César Carrega. 